This manuscript is a preprint and will be submitted to a peer-review journal soon. This article has yet to undergo peer-review and subsequent versions of this manuscript may have slightly different content after a peer review. If accepted, the final version of this manuscript will be available via the 'Peer-reviewed Publication DOI' link on the right-hand side of this webpage. Please feel free to contact any of the authors; we welcome any feedback. 


\title{
Lockdown caused by COVID-19 pandemic reduces air pollution in cities worldwide
}

Asheshwor Man Shrestha ${ }^{1}$, Uttam Babu Shrestha ${ }^{1, *}$, Roshan Sharma ${ }^{2}$, Suraj Bhattarai ${ }^{1}$, Hanh Ngoc Thi Tran ${ }^{3}$, Maheswar Rupakheti ${ }^{4}$

${ }^{1}$ Global Institute for Interdisciplinary Studies, Kathmandu, Nepal

${ }^{2}$ Centre for Urban Research, RMIT University, Melbourne, VIC, Australia

${ }^{3}$ School of Marketing and Management, The University of Adelaide, Adelaide, SA, Australia ${ }^{4}$ Institute for Advanced Sustainability Studies, Potsdam, Germany

*Corresponding author: Uttam Babu Shrestha (Email: ubshrestha@yahoo.com)

\begin{abstract}
Drastic measures such as lockdown taken by countries worldwide to contain spread of COVID19 have influenced air pollution dynamics substantially, at a planetary scale. Several media reported the lockdown induced air pollution reduction based on quickly assembled satellite observations. However, a global-scale analysis of such reduction in air pollution backed by quality data collected from ground stations across the world and the effects of lockdown to it are missing. Here, we investigate changes in concentrations of six air pollutants: $\mathrm{PM}_{2.5}, \mathrm{PM}_{10}, \mathrm{O}_{3}$, $\mathrm{SO}_{2}, \mathrm{CO}$, and $\mathrm{NO}_{2}$ in 40 cities between February, March 2019 and 2020. The mean monthly concentrations of $\mathrm{PM}_{2.5}$ and $\mathrm{PM}_{10}$ in February and March of 2020 were found consistently lower than in 2019 in most of the cities. After lockdown, declines of anthropogenic pollutants such as $\mathrm{NO}_{2}, \mathrm{CO}, \mathrm{PM}_{2.5}$ and $\mathrm{PM}_{10}$ concentrations were seen in 19, 9, 8 and 7 cities respectively. Improvement in air quality following lockdown was observed in the world's most polluted cities including Bangalore, Beijing, Bangkok, Delhi, and Nanjing, as well as the world's major trade centers including New York, London, Paris, Seoul, Sydney, and Tokyo. More visible reduction of air pollution remains to be seen if the lockdown is prolonged. Nevertheless, such reductions are expected to be temporary because the levels are likely to go up again once the situation gets back to normal.
\end{abstract}




\section{Introduction}

The COVID-19 pandemic has impacted every aspect of human life and the global economy. As of April 15, 2020, the coronavirus (COVID-19) has infected over 1.92 million people and caused $\sim 127,000$ deaths in 185 countries and territories across the world (https://coronavirus.jhu.edu/map.html). The number of new cases and deaths is increasing at an alarming rate with no signs of control yet, making the estimates of its economic and other impacts uncertain. The global cost of the COVID-19 pandemic could range from $\$ 2.0$ to 4.1 trillion, equivalent to a loss of between $2.3 \%$ and $4.8 \%$ of global gross domestic product (ADB 2020). It will make more than 25 million people unemployed by the end of 2020 depending on how quickly the economy recovers in the second half of the year and how effectively policy measures will boost labour demand (ILO 2020).

Depending on the level of COVID-19 impact in each country, as well as country-specific situations and capacity, the world's governments are adopting different levels of interventions including travel restrictions and lockdown to contain the spread of the highly contagious virus. The lockdown restricting movement of people and shutting down business and industrial establishments was first imposed on January 23, 2020 in the city of Wuhan in China where the first case of this deadly virus was reported and later followed by other countries (Jing 2020). From March 25, 2020, India, the second-most populous country in the world with 1.3 billion people, went into lockdown (Chandrashekhar 2020). Although lockdown ended in Wuhan, China on April 8 after 76 days (Kuo 2020), more than 3.9 billion people or a half of the world's population living in 90 different countries around the world are currently under containment as a measure to maintain social distancing (Sandford 2020). The extent of lockdown varies across countries and cities around the world. Nonetheless, the lockdown has halted quite significantly all forms of transport (flights, trains, automobiles), factories, shops, markets, and other economic and social activities.

Despite the severe impacts of lockdown on people's social life, global mobility and economy, there are reports that lockdown has temporarily improved environmental conditions. For example, the lockdown improved the air quality of the 103 cities in India - the most polluted 
country in the world which has 21 out of the 30 world's most polluted cities (Singh and Chakraborty 2020). Air pollution is the single largest environmental health risk in the world; ca. seven million people die prematurely every year globally as a result of exposure to air pollution, more than $91 \%$ of the world's population lives in places where air quality exceeds the World Health Organization's guidelines (WHO 2020). PM $_{2.5}$ is a common cause for adverse health outcomes such as chronic obstructive pulmonary disease (COPD) and lower respiratory infection (LRI) causing death of nearly three million people globally (GBD 2018). $\mathrm{NO}_{2}$ is the leading source of childhood asthma in urban areas globally (Achakulwisut et al. 2019). Likewise, acute to chronic exposures to $\mathrm{SO}_{2}, \mathrm{CO}$, and $\mathrm{O}_{3}$ can harm the human respiratory system, causing breathing problems including occasional death (Chen et al. 2007, Brown 2009). Air pollution also causes adverse impacts on society, economy, and the environment including climate change. It is in fact a major public health, environmental and developmental challenge of our time (Haines et al. 2017). Therefore, understanding this temporary improvement in air quality at the planetary scale provides a unique opportunity to study processes and implications of policy changes to reduce air pollution in future.

There are media reports, primarily based on satellite images, about reduction of air pollution due to the lockdown globally, and some recent scientific studies conducted in a small number of countries (He et al. 2020) and cities (Cadotte 2020) indicated such reductions. While satellite images are useful to monitor air pollution, cautions should be taken to prevent the erroneous interpretation of satellite images (see https://atmosphere.copernicus.eu/flawed-estimates-effectslockdown-measures-air-quality-derived-satellite-observations). To the best of our knowledge, there is no global-scale examination of the impact of COVID-19 induced lockdown on air quality. Here, we provide the first global insight on air pollution by utilizing vast networks of ground-based air quality monitoring stations from 40 major cities from 35 countries across the six continents. The air quality data is collected from 301 ground-based stations for February and March of 2019 and 2020 to compare both monthly and yearly changes post-COVID lockdown. We also examine the effect of lockdown on the daily concentrations of air pollutants of the last 100 days from January 1 to April 9, 2020. 


\section{Materials and Methods}

\subsection{Selection of the world's cities}

We selected 40 major cities around the world (Figure 1) based on (i) the historical level of air pollution in the city (a mix of cities with dirty and clean air), (ii) reported COVID-19 cases in that city (a mix of the high and low impacted city), (iii) geographical setting and developmental stage (balance between high, middle, and low income countries of all continent), (iv) city lockdown history (early and late beginnings of lockdowns), and (v) availability of air pollution data. We used the World Air Quality Index portal (WAQI) (www.aqien.org) to download daily records from 301 air pollution monitoring stations spread across 40 selected cities of 35 countries. We deliberately exclude cities around the equator where air quality is often influenced by the emissions from forest fires, and cities near the deserts that often get hit by sand and dust storms. Therefore, most of the cities selected for this study are affected heavily by anthropogenic emissions, and a reduction in air pollution is expected in those cities as a result of lockdown.

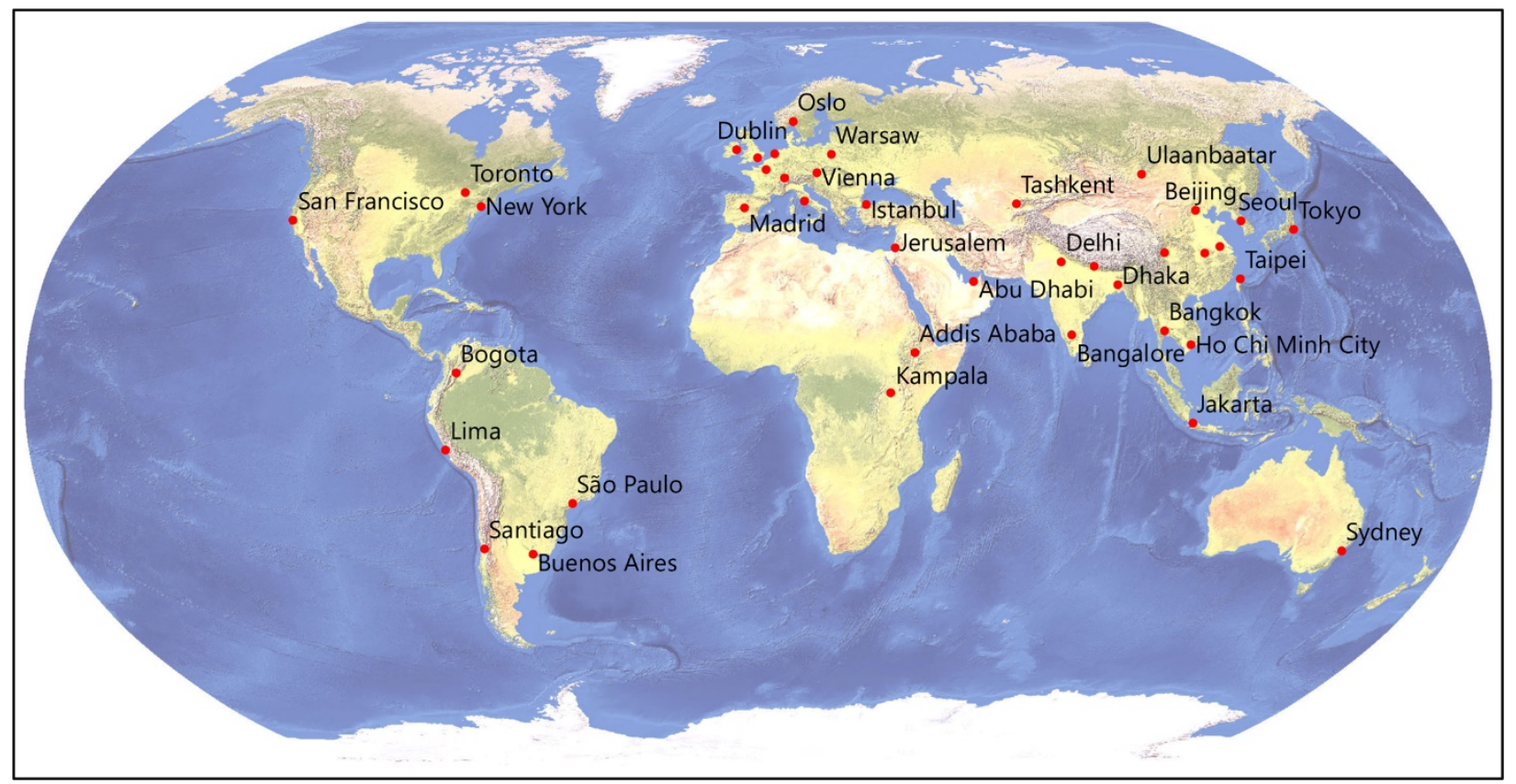

Figure 1.Selected cities used for analysis of changes in the concentrations of air pollutants. 


\subsection{Selection of air pollutants}

Normally, air quality is evaluated by measuring the atmospheric concentrations of six pollutants: fine particulate matter $\left(\mathrm{PM}_{2.5}\right.$, mass concentration of particles with diameters $\left.\leq 2.5 \mathrm{um}\right)$, coarse particulate matter $\left(\mathrm{PM}_{10}\right.$, mass concentration of particles with diameters $\left.\leq 10 \mathrm{um}\right)$, ground-level ozone $\left(\mathrm{O}_{3}\right)$, nitrogen dioxide $\left(\mathrm{NO}_{2}\right)$, sulfur dioxide $\left(\mathrm{SO}_{2}\right)$, and carbon monoxide $(\mathrm{CO})$ (EPA 2014). All of them except $\mathrm{O}_{3}$ have primary sources, such combustion sources as the automobiles and industries, while $\mathrm{O}_{3}$ is formed in the atmospheric from precursor gaseous species, emitted mostly from primary sources, in presence of sunlight. Therefore, we selected $\mathrm{PM}_{2.5}, \mathrm{PM}_{10}, \mathrm{NO}_{2}$, $\mathrm{O}_{3}, \mathrm{SO}_{2}$ and $\mathrm{CO}$ to investigate the changes in air quality among cities before and during lockdowns.

\subsection{Data and analysis}

We used publicly available air quality data provided by the World's Air Pollution: Real-time Air Quality Index (WAQI project) which curates air quality data collected from $>12,000$ groundbased air quality monitoring stations (primarily located at/near the US embassies and consulates) situated in 1,000 major cities in more than 100 countries in six continents (https://aqicn.org/). It must be noted that the data from WAQI are from the stations managed by government agency or any institution of the respective country and may not be always fully validated. We used daily concentrations of air pollutants collected from multiple WAQI stations where available for further analysis (Table 1). We collected the lockdown dates for the selected cities from local and global media reports (Table 1). By 'lockdown', we meant restrictions on vehicles, commercial flights except for cargo and charter, and prohibitions of commercial activities, except for essential services, resulting in a temporary shutdown of air pollution sources from these activities. Although we cross-verified the accuracy of the starting dates of lockdown by looking at multiple media reports, there may be some discrepancies due to any errors in media reporting and differences in time zones. We assume air quality in February and March of 2019 was under

the business as usual conditions and hence considered normal and change in air quality in February and March of 2020 is caused primarily due to the country-specific response to containing the spread of COVID-19. Therefore, we compared the mean monthly concentration of the six air pollutants of February and March of 2019 with February and March of 2020 using 
welch two sample t-test. As dates of lockdown vary, we also examined the daily changes in concentrations of these air pollutants from January 1 to April 9 (100 days) to investigate the effect of lockdown on their daily concentrations of air pollutants through linear regression using lockdown as dummy variable.

\section{Results and discussions}

A consistent reduction in $\mathrm{PM}_{2.5}$ concentration was observed among 17 cities in February 2020 compared to February 2019, and 14 cities (increase in Oslo, Vienna, Warsaw) in March 2020 than that of March 2019 (Figure 2). Maximum decline in mean monthly concentration of $\mathrm{PM}_{2.5}$ in February was observed in Vienna (-57.1\%), Paris (-53.2\%), Amsterdam (-47.5\%), London ($45.6 \%$ ), and Dublin (-45.2\%). It is worth mentioning here that in absolute term these cities already have cleaner air, i.e., PM2.5 concentrations are very low compared to heavily polluted cities. Likewise, in March, a maximum decline was seen in New York (-37.0\%), Sydney (35.1\%), Abu Dhabi (-32.4\%), Nanjing (-31.3\%), Ulaanbaatar (-25.6\%). In the cities, where anthropogenic activities are a major source of emissions of air pollutants sharp declines in the $\mathrm{PM}_{2.5}$ levels were seen, notably in highly polluted cities like Bangalore, Bangkok, Beijing, Delhi, Nanjing, Wuhan, Ulaanbaatar in Asia and also in developed cities like Madrid, New York, Paris, Seoul, Sydney, Tokyo. In contrast, an increase in $\mathrm{PM}_{2.5}$ concentrations was observed in Addis Ababa (lockdown on April 1 20202) and Ho Chi Minh City (lockdown on March 31, 2020). An increase in February $\mathrm{PM}_{2.5}$ concentration and decrease in March in Bangkok and Kathmandu are likely due to the lockdown that started in the last week of March. In regards to daily $\mathrm{PM}_{2.5}$ concentrations from January 1, 2020 to April 9, 2020, eight cities Amsterdam, Bangalore, Delhi, Lima, Nanjing, New York, Ulaanbaatar, Wuhan showed significant decrease (linear regression, $p$ $<0.05$ ) while there was an increase in Buenos Aires, Santiago and Vienna after accounting the lockdown imposed date (Figure 3). 


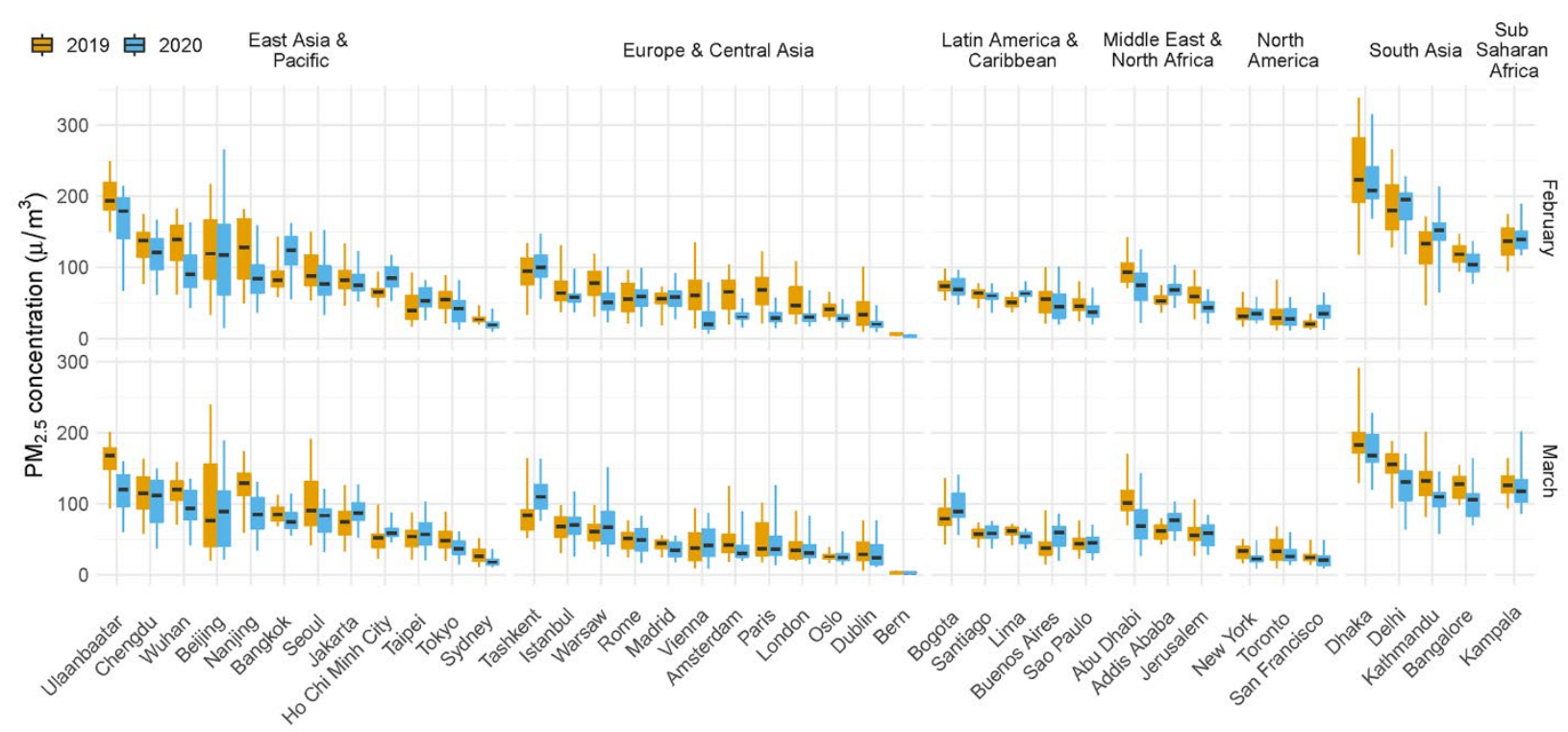

Figure 2. The box and whisker plots of daily average $\mathrm{PM}_{2.5}$ concentrations during February-March 2020 and 2019. The top and bottom of each box represents $75^{\text {th }}$ percentile and $25^{\text {th }}$ percentile respectively and the upper and lower whisker represents $90^{\text {th }}$ percentile and $10^{\text {th }}$ percentile respectively. The horizontal bar in each box represents the median. 


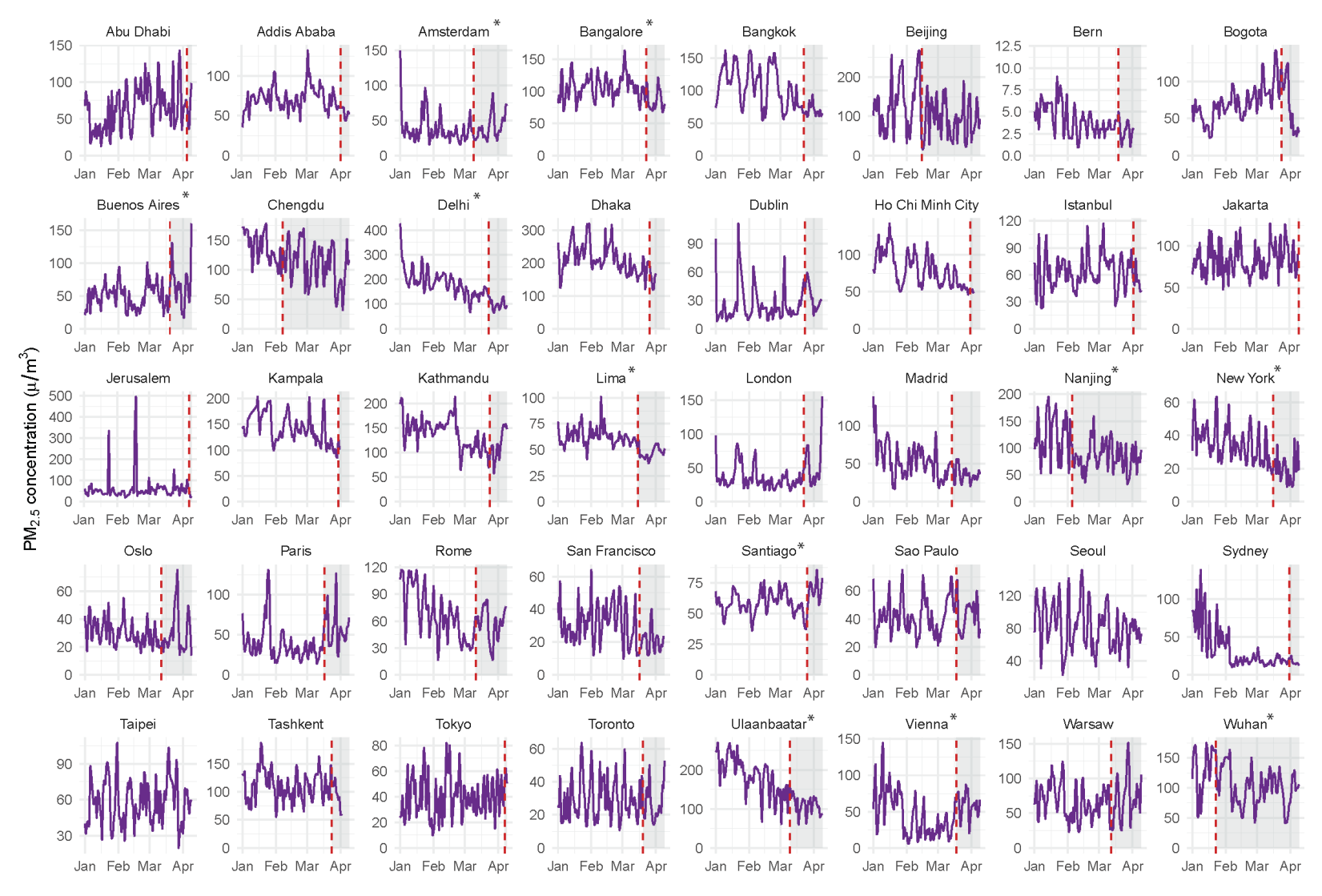

Figure 3. Time series of daily $\mathrm{PM}_{2.5}$ concentrations from January 1 to April 9, 2020 in 40 cities across the globe. Vertical red dashed line shows the lockdown date and * denotes significant linear trends.

Only 29 cities have complete $\mathrm{PM}_{10}$ concentrations data of which 16 cities showed a statistically significant decline in $\mathrm{PM}_{10}$ in February 2020 compared to February 2019 and 11 cities showed similar declines in March 2020 than in March 2019. Maximum decline in mean monthly concentration of $\mathrm{PM}_{10}$ in February was observed in Vienna (-60.7\%), Bern (-53.3\%), Paris ($52.7 \%)$, Warsaw (-45.9\%) and Dublin (-44.3\%). Maximum declines were seen in Ulaanbaatar (43.4\%), Delhi (-32.5\%), Nanjing (-31.8\%), Wuhan (-26.8\%), and Lima (-25.7\%) in March. A consistent decline in $\mathrm{PM}_{10}$ in both February and March of 2020 was observed in 7 cities: Bangkok, Beijing, Lima, Nanjing, Tokyo, Ulaanbaatar and Wuhan (Figure 4). The time series of daily $\mathrm{PM}_{10}$ concentrations of the last 100 days in 2020 showed that after the lockdown, a statistically significant decrease in $\mathrm{PM}_{10}$ concentrations was observed in seven cities namely Bangalore, Beijing, Delhi, Lima, Nanjing, Ulaanbaatar, and Wuhan while Kathmandu and 
Vienna both saw increases (Figure 5). The local meteorology and seasonal forest fire might have played a role in such increase, particularly stronger wind speeds lifting soil and road dust into air in Kathmandu and stronger winds diluting $\mathrm{PM}_{10}$ concentration in February in Vienna.

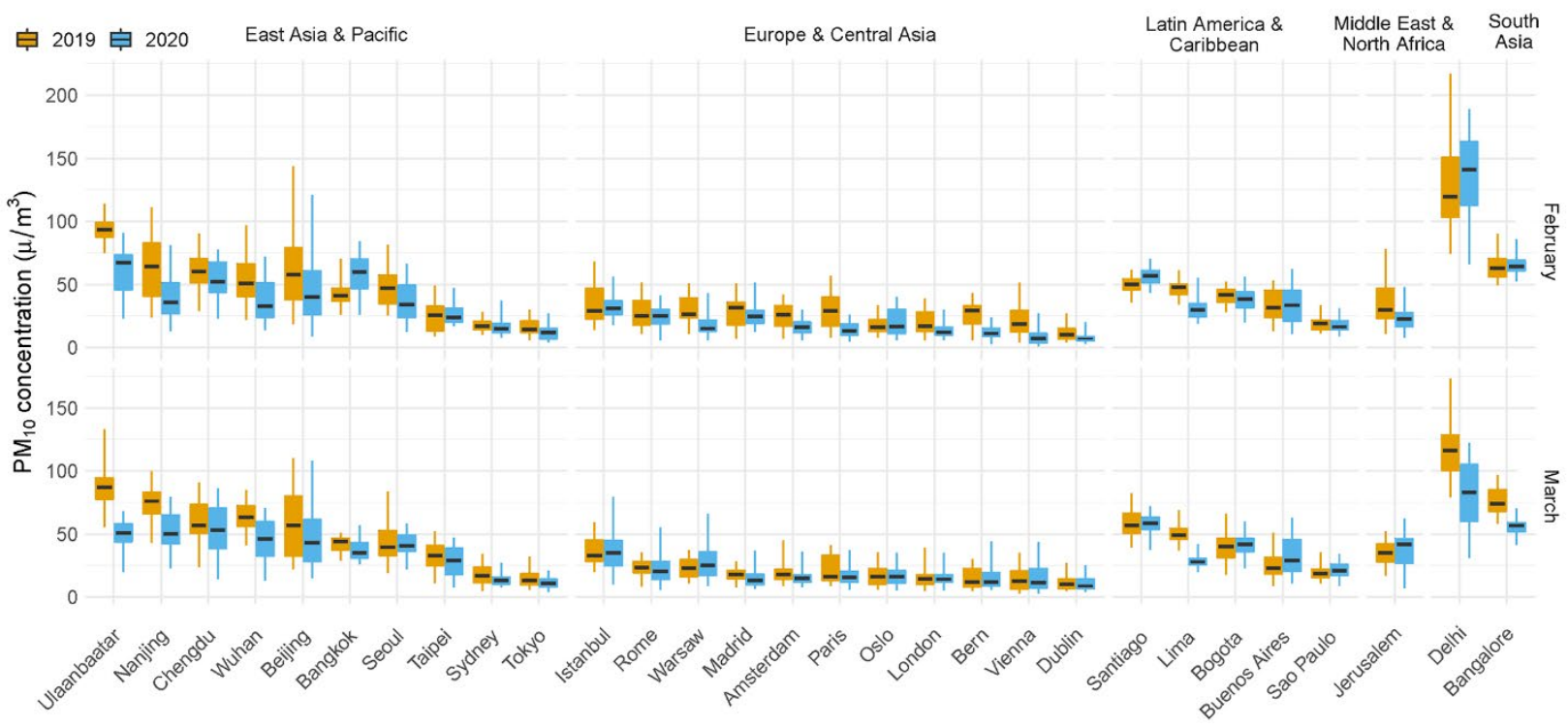

Figure 4. The box and whisker plots of daily average $\mathrm{PM}_{10}$ concentrations during FebruaryMarch 2020 and 2019. The top and bottom of each box represents $75^{\text {th }}$ percentile and $25^{\text {th }}$ percentile respectively and the upper and lower whisker represents $90^{\text {th }}$ percentile and $10^{\text {th }}$ percentile respectively. The horizontal bar in each box represents the median. 
Out of the 31 cities with complete data, decreased $\mathrm{NO}_{2}$ concentration in February and March 2020 was observed in 10 and 17 cities respectively (Figure 6). There are mixed trends (increases in some cities while decreases in others) in $\mathrm{NO}_{2}$ for both months; an increase in four cities Wuhan $(+62.0 \%$ in February, $+11.3 \%$ in March), Nanjing $(+35.1 \%$ in February, $+62.4 \%$ in March), Chengdu ( $+30.9 \%$ in February, $+73.9 \%$ in March), Warsaw ( $+4.0 \%$ in February, $+8.2 \%$ in March) while a decrease in five cities; Madrid (-33.3\% in February, $-47.5 \%$ in March, Paris (-

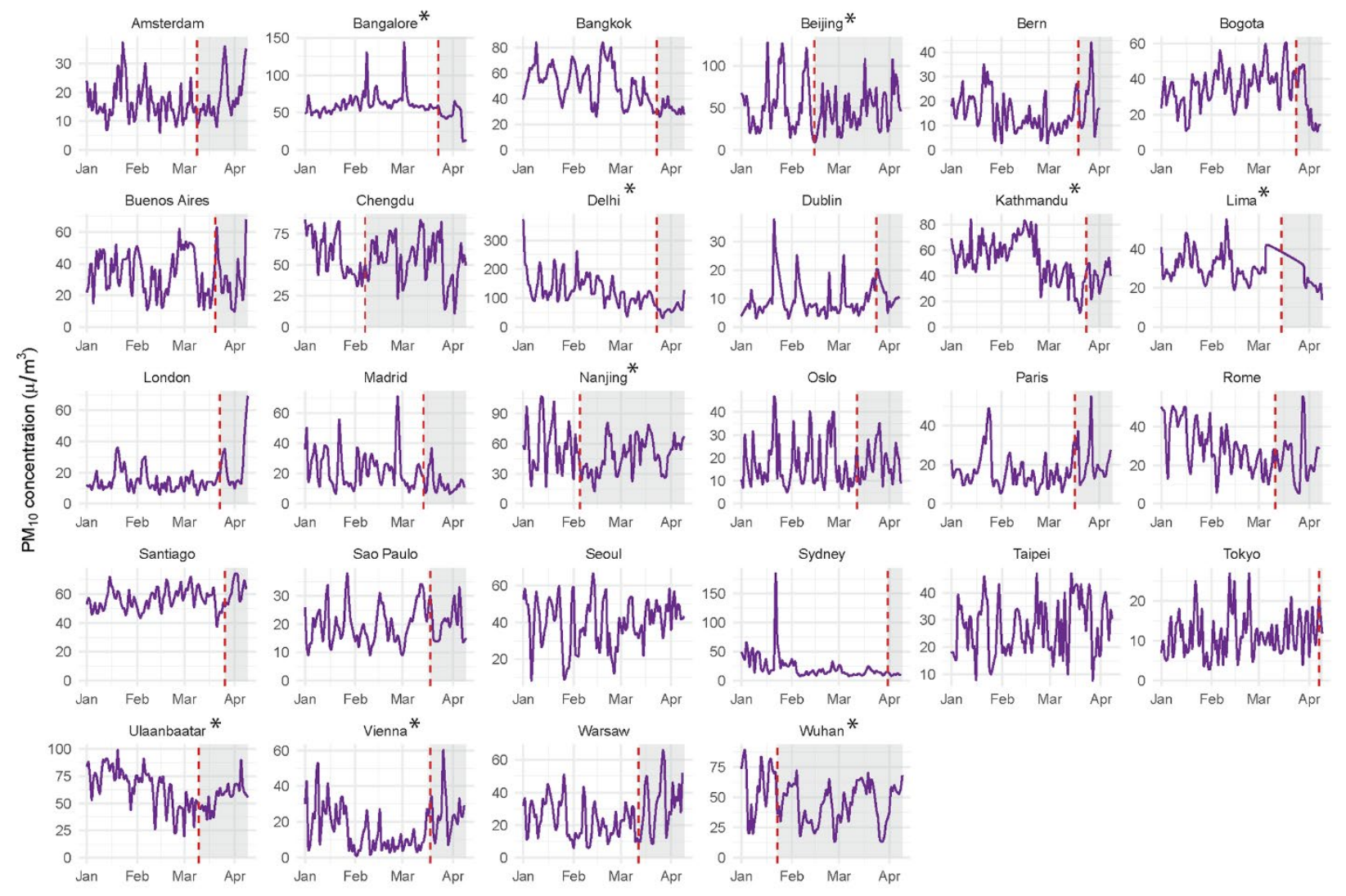

Figure 5. Time series of daily $\mathrm{PM}_{10}$ concentrations from January 1 to April 9, 2020 in 28 cities across the globe. Vertical red dashed line shows the lockdown date and $*$ denotes significant linear trends. 


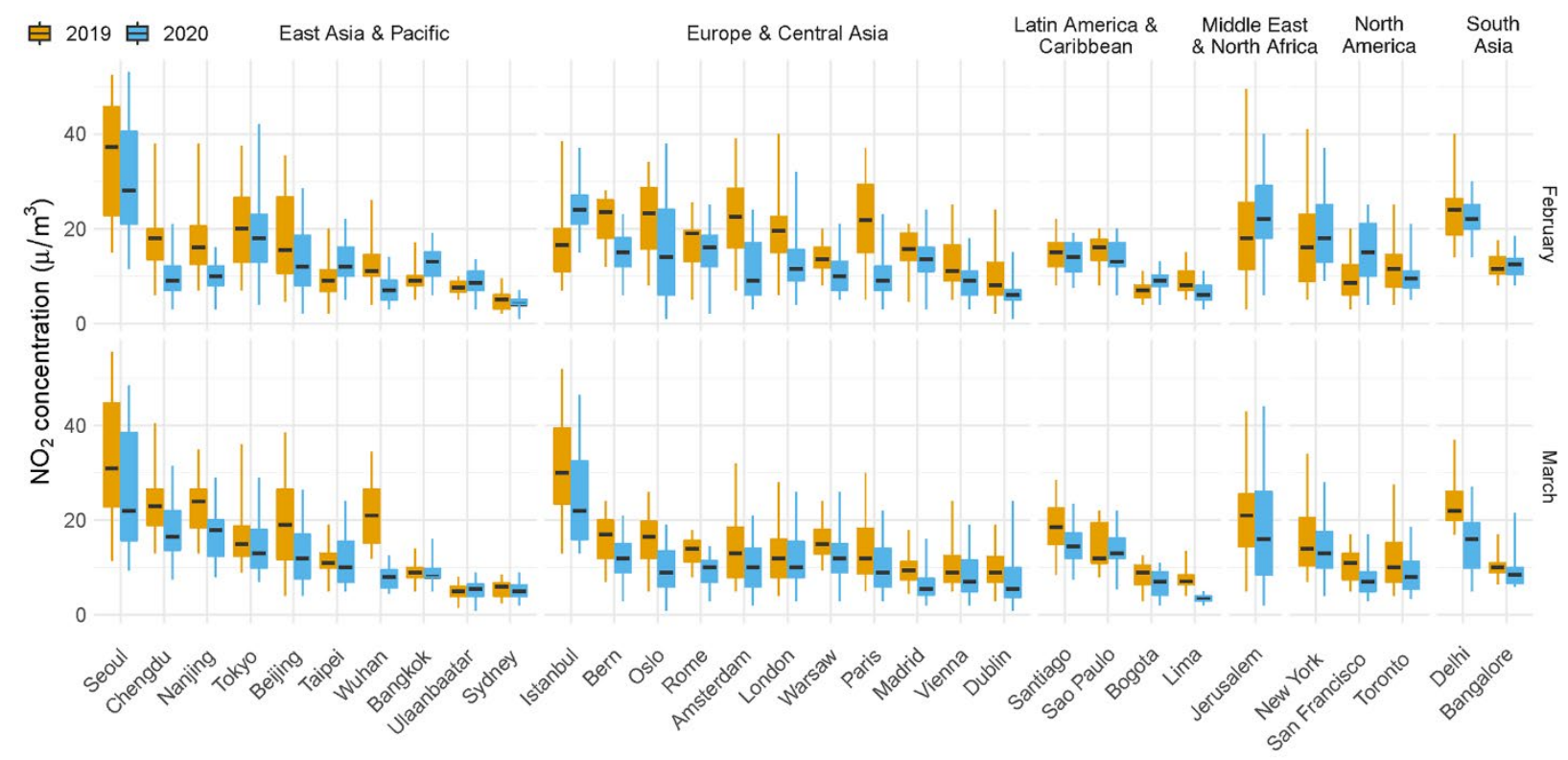

Figure 6. The box and whisker plots of daily average $\mathrm{NO}_{2}$ concentrations during FebruaryMarch 2020 and 2019. The top and bottom of each box represents $75^{\text {th }}$ percentile and $25^{\text {th }}$ percentile respectively and the upper and lower whisker represents $90^{\text {th }}$ percentile and $10^{\text {th }}$ percentile respectively. The horizontal bar in each box represents the median.

$33.1 \%$ in February, $-5.6 \%$ in March), Oslo (-28.3\% in February, -39.7\% in March), Bern (-27.0\% in February, $-19.1 \%$ in March), Vienna (-18.1\% in February, $-4.4 \%$ in March), Lima (-4.6\% in February, $-26.7 \%$ in March). However, the significant decline (linear regression, $\mathrm{p}<0.05$ ) in $\mathrm{NO}_{2}$ was seen in the daily $\mathrm{NO}_{2}$ concentration records after the lockdown was imposed; a significant decline in $\mathrm{NO}_{2}$ concentration was observed in 19 cities (Amsterdam, Bangalore, Beijing, Bern, Bogota, Chengdu, Delhi, Lima, Madrid, Nanjing, New York, Oslo, Paris, Rome, San Francisco, Santiago, Sao Paulo, Warsaw, Wuhan) (Figure 7). Three Chinese cities Chengdu, Nanjing and Wuhan have witnessed consistent increase in $\mathrm{NO}_{2}$ concentrations in Feb-Mar of 2020 than that of Feb-Mar of 2019 but the daily $\mathrm{NO}_{2}$ concentrations in these cities were also significantly reduced after lockdown.

Comparison of $\mathrm{O}_{3}$ concentrations between February 2020 vs. February 2019 and March 2020 vs. March 2019 from available data of 26 cities showed a mixed trend (Figure 8). $\mathrm{O}_{3}$ concentrations increased in 11 cities in February and in 5 cities in March. While it decreased in 3 cities in February and 4 cities in March. Lima (-42.5\%) has maximum decrease followed by Bangkok (17.6\%) in February and Bangkok (-39.5\%) and Bangalore (-10.6\%) in March. On the other hand, Tokyo ( $+31.9 \%$ in February, $+15.2 \%$ in March), Madrid ( $+26.9 \%$ in February, $37.8 \%$ in March), 


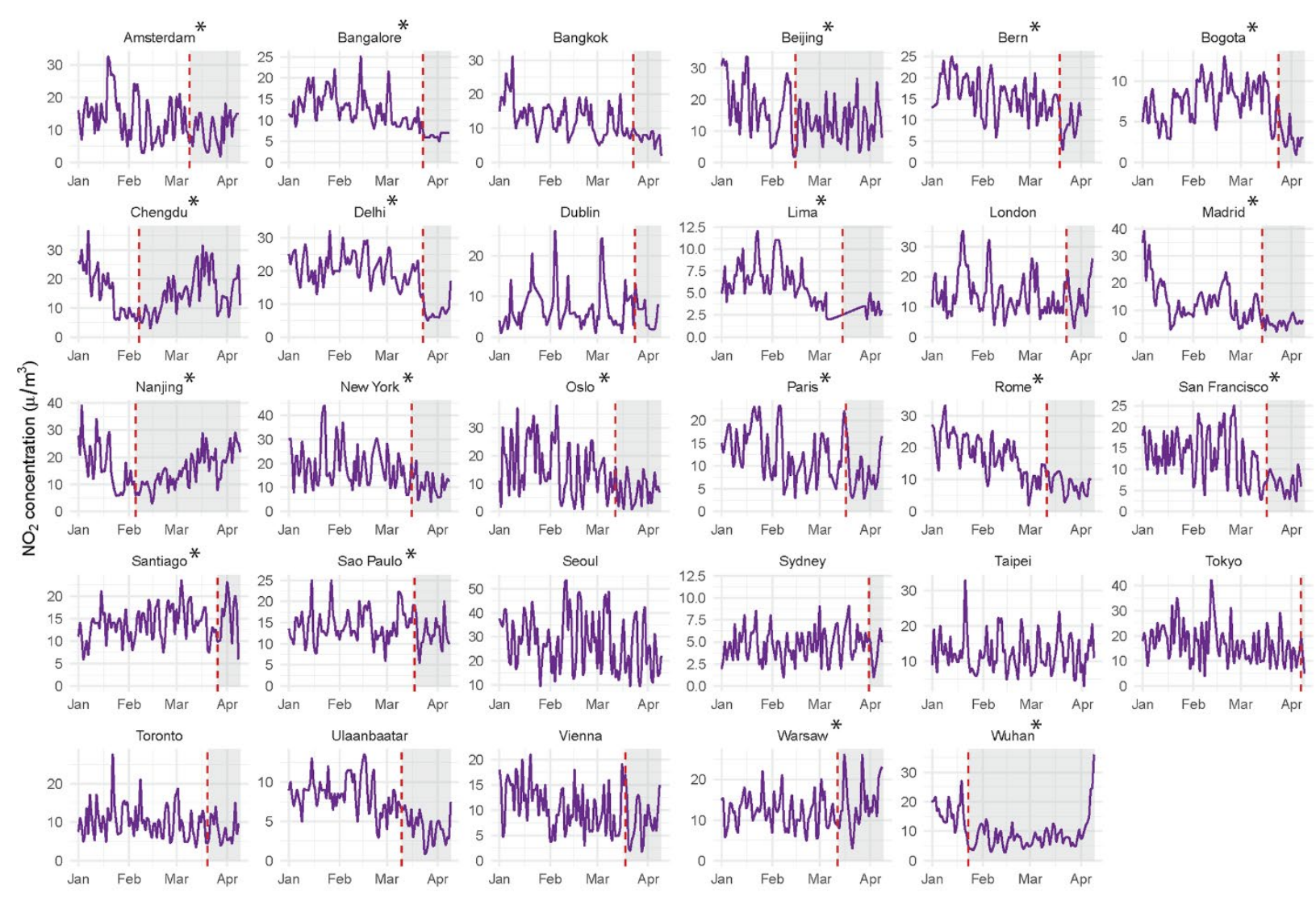

Figure 7. Time series of daily $\mathrm{NO}_{2}$ concentrations from January 1 to April 9, 2020 in 29 cities across the globe. Vertical red dashed line shows the lockdown date and $*$ denotes significant linear trends.

and Toronto $(+17.8 \%$ in February, $+3.6 \%$ in March) saw maximum increases. These mixed trends were consistent even in daily $\mathrm{O}_{3}$ concentrations after lockdown; decrease in five cities (Bangalore, Bangkok, Madrid, New York, Toronto) while increase in four (Chengdu, London, Warsaw, Wuhan) cities (Figure 9). As $\mathrm{O}_{3}$ is a secondary air pollutant, the local availability of precursor gases (nitrogen oxides and volatile organic compounds) and local meteorology (sunlight and temperature) influences the production and destruction of $\mathrm{O}_{3}$ in air. These two factors, particularly more incoming sunlight in March than February, are expected to vary widely across the cities and continents, and hence the $\mathrm{O}_{3}$ concentrations too. 


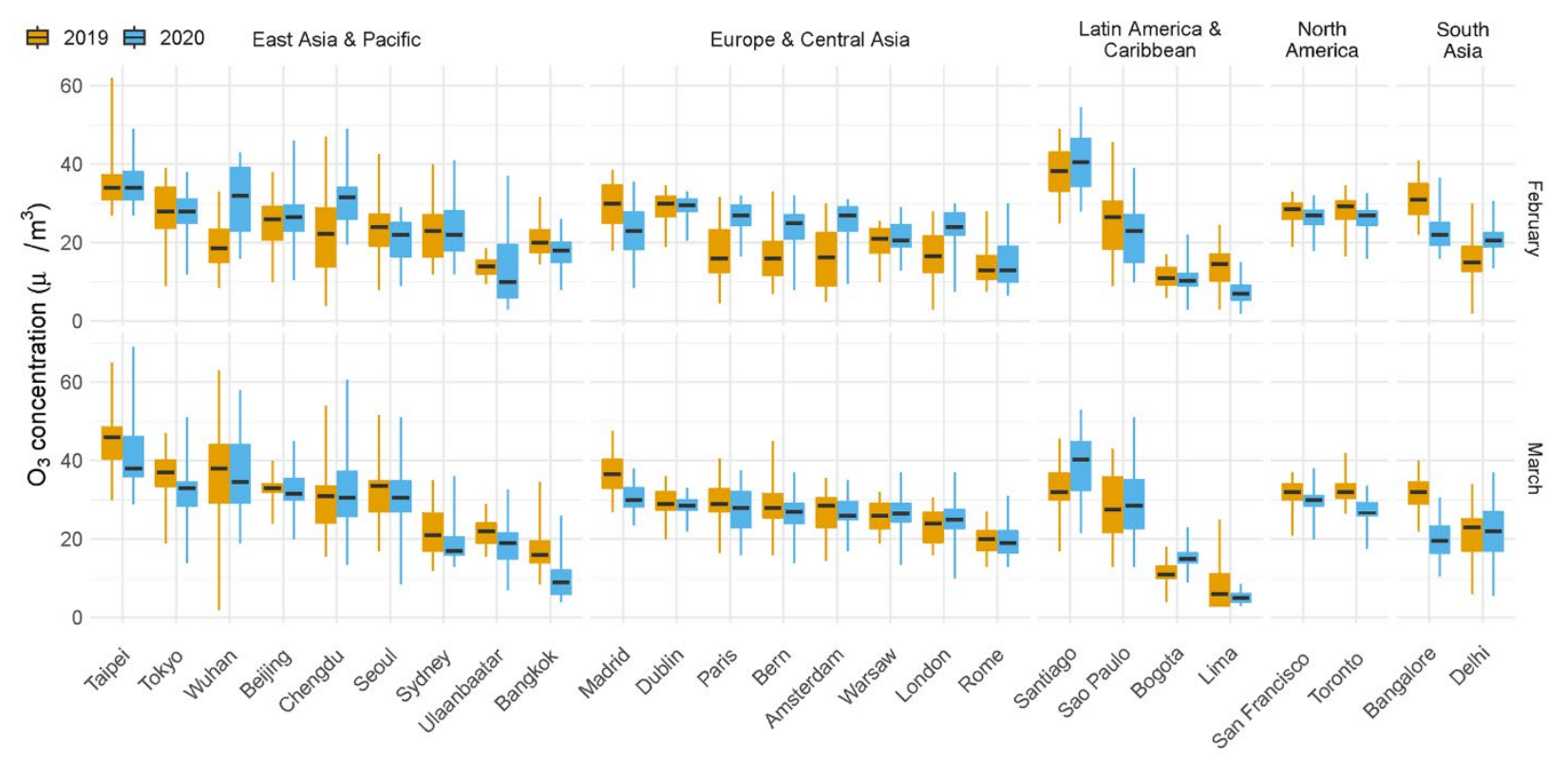

Figure 8. The box and whisker plots of daily average $\mathrm{O}_{3}$ concentrations during February-March 2020 and 2019. The top and bottom of each box represents $75^{\text {th }}$ percentile and $25^{\text {th }}$ percentile respectively and the upper and lower whisker represents $90^{\text {th }}$ percentile and $10^{\text {th }}$ percentile respectively. The horizontal bar in each box represents the median.

There is also a mixed trend in $\mathrm{SO}_{2}$ concentrations across cities; seven cities saw lower monthly mean $\mathrm{SO}_{2}$ concentration in February 2020 compared to February 2019 and 12 cities have declining $\mathrm{SO}_{2}$ in March 2020 compared to March 2019 (Figure 10). In contrast, four cities (Bangalore, Istanbul, Santiago, Ulaanbaatar) in February 2020 and five cities (Istanbul, London, Santiago, Ulaanbaatar, Toronto) in March 2020 had higher $\mathrm{SO}_{2}$ concentrations. Maximum decline in $\mathrm{SO}_{2}$ was observed in Lima (-75.2\%), followed by Nanjing (-38.9\%) and Beijing ($36.8 \%$ ) in February 2020 and Bogota (-64.8\%) observed a maximum decline followed by Lima (-60.4\%) and Nanjing (-53.3\%) in March 2020. The daily $\mathrm{SO}_{2}$ concentration also showed mixed trends; after the lockdown, statistically significant decrease in five cities (Beijing, Delhi, Madrid, Nanjing, Vienna) and increase in 4 cities (Buenos Aires, London, Toronto, Ulaanbaatar) (Figure 11).

Mean monthly CO concentrations of February 2020 in Amsterdam (-35.1\%), London (-48.3\%), Lima (-27.3\%), Nanjing (23.8\%), Seoul (-13.4\%), Chengdu (-29.1\%) were lower while higher in Bangalore $(+14.8 \%)$, Bogota $(+15.8 \%)$, Istanbul $(+171.0 \%)$, Jerusalem $(+465.2 \%)$, San Francisco (+22.6\%), Taipei (24.3\%), Warsaw (+28.1\%) than that of February 2019 (Figure 12). 
In March 2020, CO concentrations decreased in 14 cities (Bangalore, Beijing, Bogota, Chengdu, Delhi, Lima, London, Nanjing, New York, San Francisco, Sao Paulo, Seoul, Toronto, Warsaw) while consistently increased in Istanbul. Daily CO concentration has significantly declined in seven cities namely (Bangalore, Bogota, Chengdu, Delhi, Lima, Nanjing, San Francisco, Sao Paulo) after the lockdown (Figure 13).

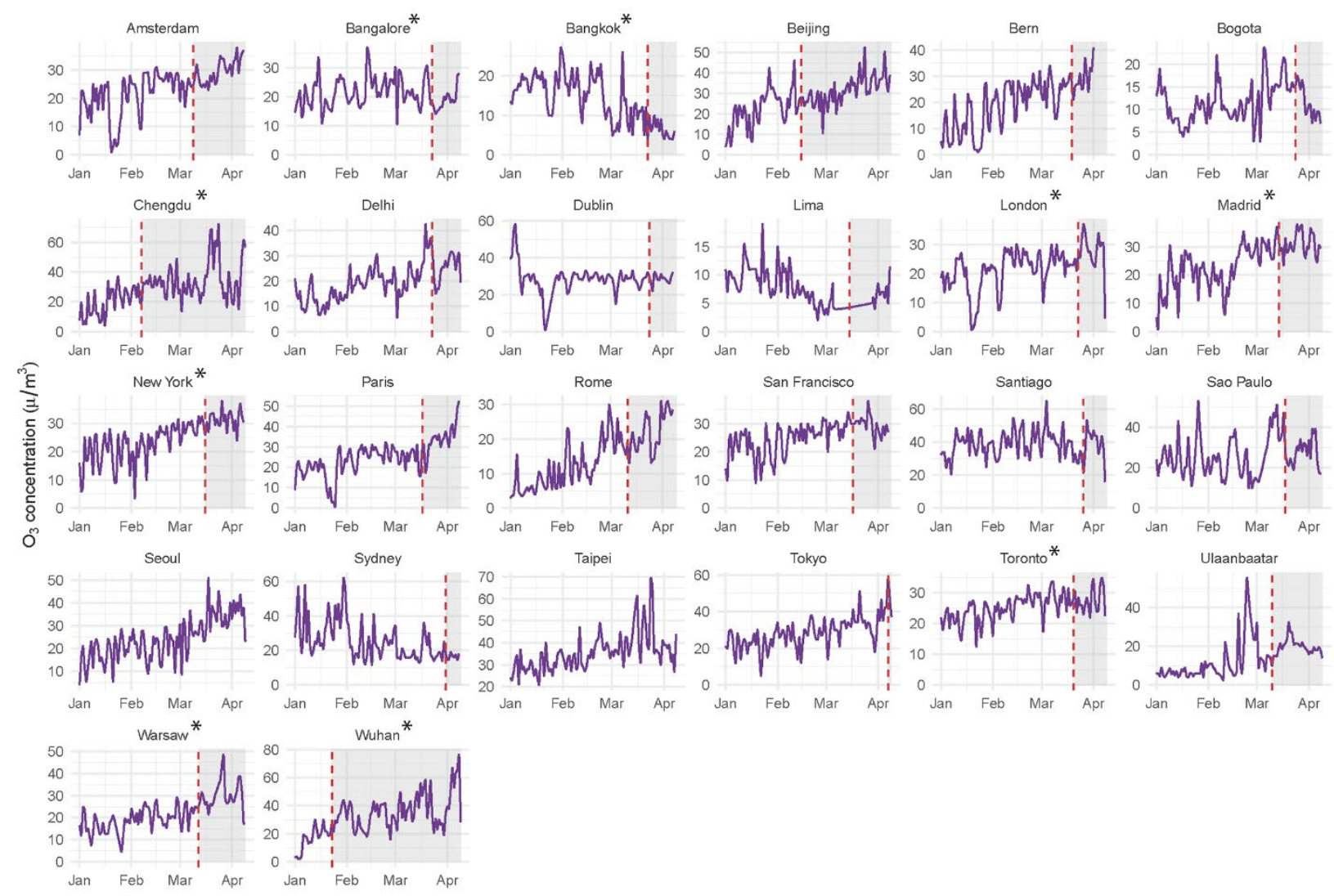

Figure 9. Time series of daily $\mathrm{O}_{3}$ concentrations from January 1 to April 9, 2020 in 26 cities across the globe. Vertical red dashed line shows the lockdown date and $*$ denotes significant linear trends.

Several other factors could have caused the mixed trends of pollutants such as $\mathrm{O}_{3}$ and $\mathrm{SO}_{2}$. First, the variation in the source of pollutants; some of the major sources of $\mathrm{SO}_{2}$ are big coal-fired power plants that might not have been shut down during lockdown and hence $\mathrm{SO}_{2}$ concentrations in the city would not have gown down. The seasonal forest fires in South Asia and Southeast 
Asia may have also influenced the air pollutant concentrations in those cities. Second, local weather can significantly affect pollution levels-higher wind speeds tend to dilute air pollutants and rainfall can wash out pollutants from air. In some cities like Delhi and Bangkok, road vehicles are a major source of $\mathrm{PM}_{2.5}$. Additionally, the high pollution level in early March prior to lockdown could have kept the monthly mean values of March this year in some cities unchanged even after shutting down traffic, businesses, and industries. In these cities, sharp decline in levels of pollutant due to lockdown is more noticeable. However, in some European cities where the sources of pollution are more varied such as from residential and commercial buildings, industrial activities, and road traffic, the changes are less apparent as such emissions could have continued despite lockdown. Furthermore, even if a city has a high contribution of the pollutant from the transport, but if the selected stations are away from roads - the impact of lockdown would be less noticeable. Emissions from natural sources such as forest fires and dust are expected to make a small change in concentrations observed in the cities unless the cities are located in or near to dominant natural sources like deserts and coasts.

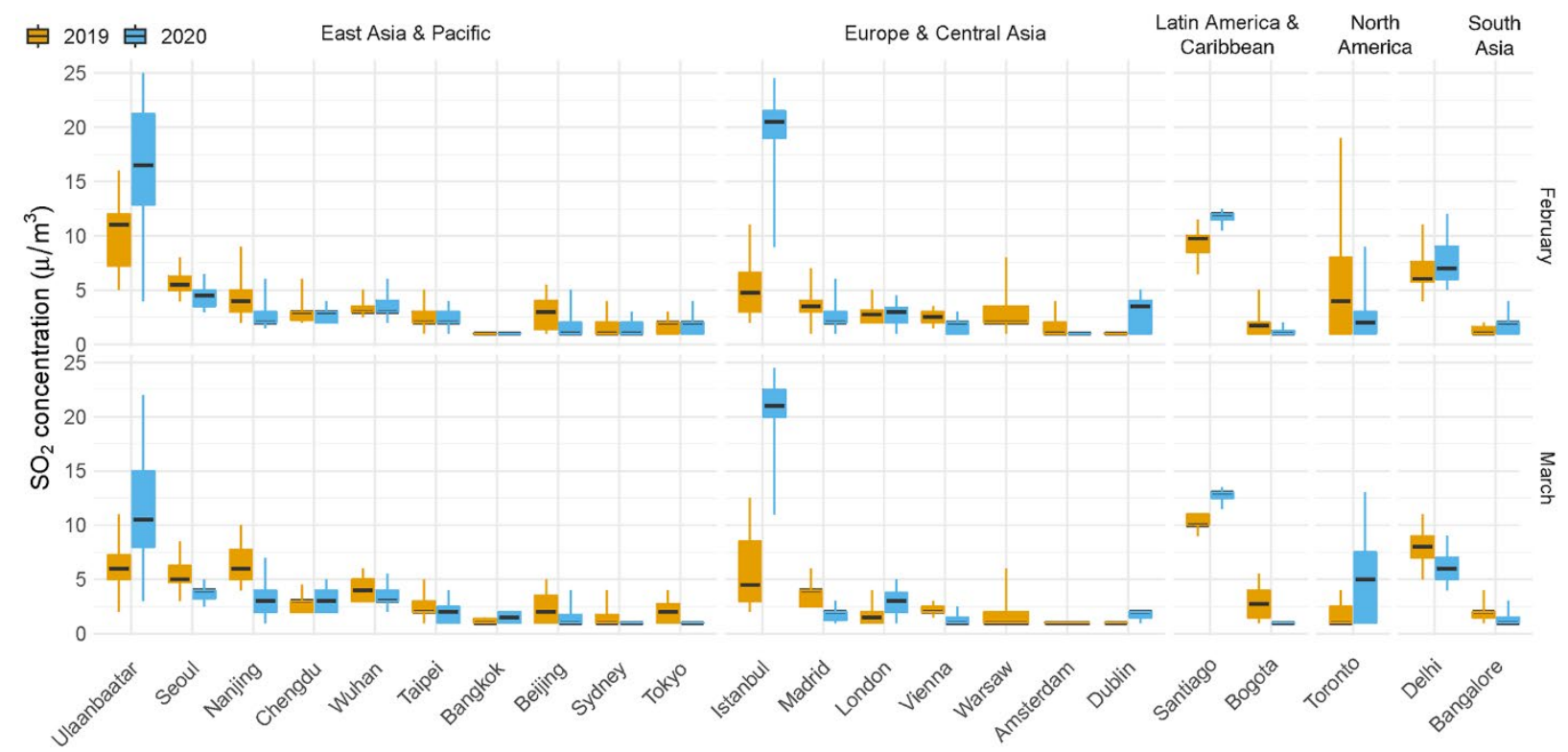

Figure 10. The box and whisker plots of daily average $\mathrm{SO}_{2}$ concentrations during FebruaryMarch 2020 and 2019. The top and bottom of each box represents $75^{\text {th }}$ percentile and $25^{\text {th }}$ percentile respectively and the upper and lower whisker represents $90^{\text {th }}$ percentile and $10^{\text {th }}$ percentile respectively. The horizontal bar in each box represents the median. 


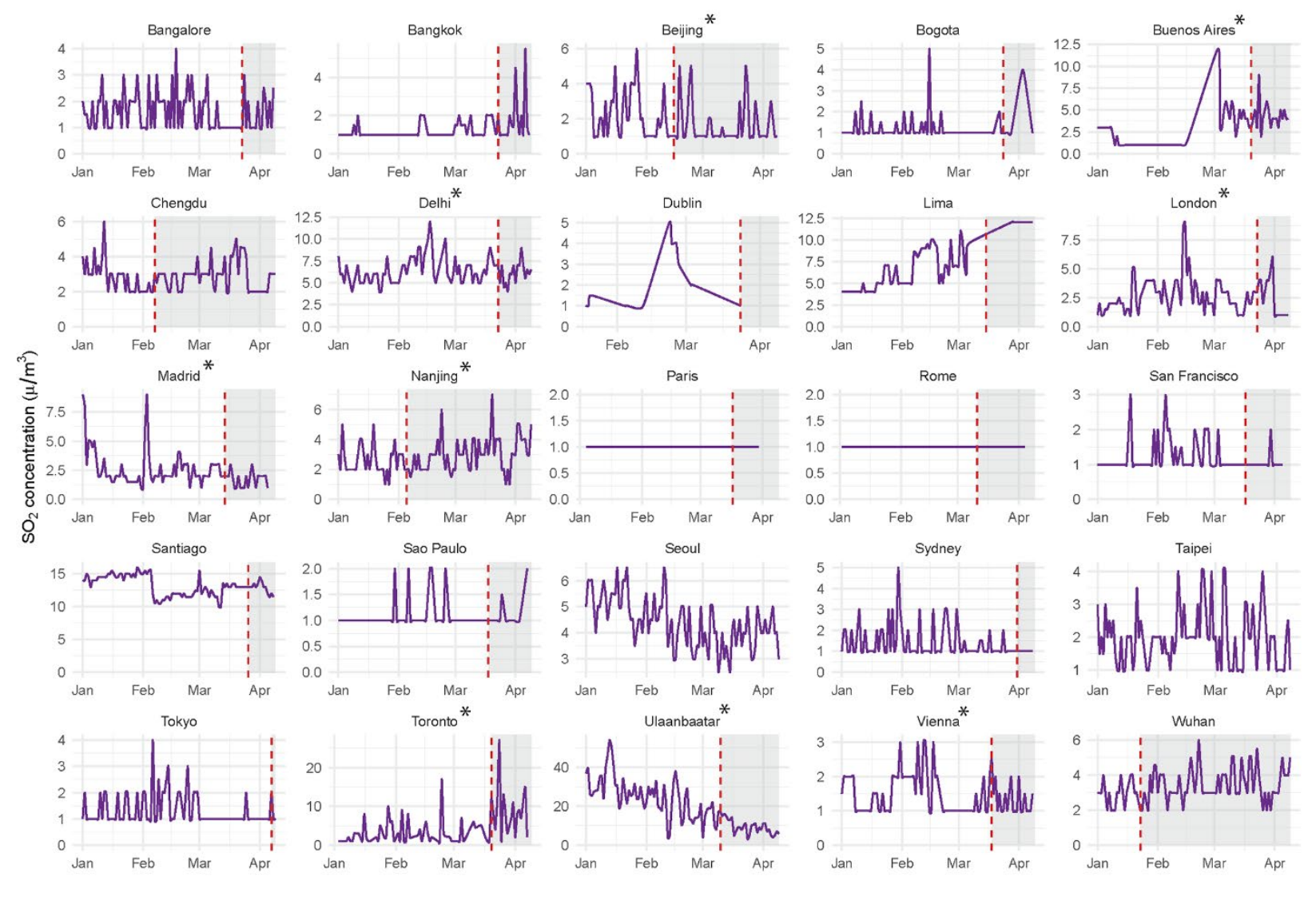

Figure 11. Time series of daily $\mathrm{SO}_{2}$ concentrations from January 1 to April 9, 2020 in 25 cities across the globe. Vertical red dashed line shows the lockdown date and $*$ denotes significant linear trends.

We observed consistent decrease in particulate matters $\left(\mathrm{PM}_{2.5}, \mathrm{PM}_{10}\right)$ and $\mathrm{NO}_{2}$ in cities like Bangalore, Beijing, Bern, Delhi, Lima, London, Madrid, New York, Paris, Seoul, Sydney, Tokyo, Ulaanbaatar, Vienna. Ozone $\left(\mathrm{O}_{3}\right)$ increased primarily in developed cities like Amsterdam, Bern, London, Madrid, New York, and Paris with few exceptions such as in Delhi, Wuhan, and Ulaanbaatar. A visible reduction of air pollution remains to be seen in cities like Addis Ababa and Ho Chi Minh City where the lockdowns were imposed in late March-early April. Evidence based on ground level stations shows reductions in concentrations of four major air pollutants $\mathrm{PM}_{2.5}, \mathrm{PM}_{10}, \mathrm{NO}_{2}$ and $\mathrm{CO}$ in majority of the world cities due to almost simultaneous lockdowns. As the higher resolution data becomes available in the future, in-depth analysis considering other factors such as influence of weather should be conducted to generate more precise estimates of this impact. Moreover, further investigations are required to quantify 
proportional contributions of emission reduction versus changes in meteorological conditions, and other benefits; health benefits such as lives saved due to, benefits to crops, and climate benefits (e.g., masking of global warming due to aerosols, change in aerosol-induced atmospheric warming, surface dimming or brightening) due to changes in air quality before and after lockdown.

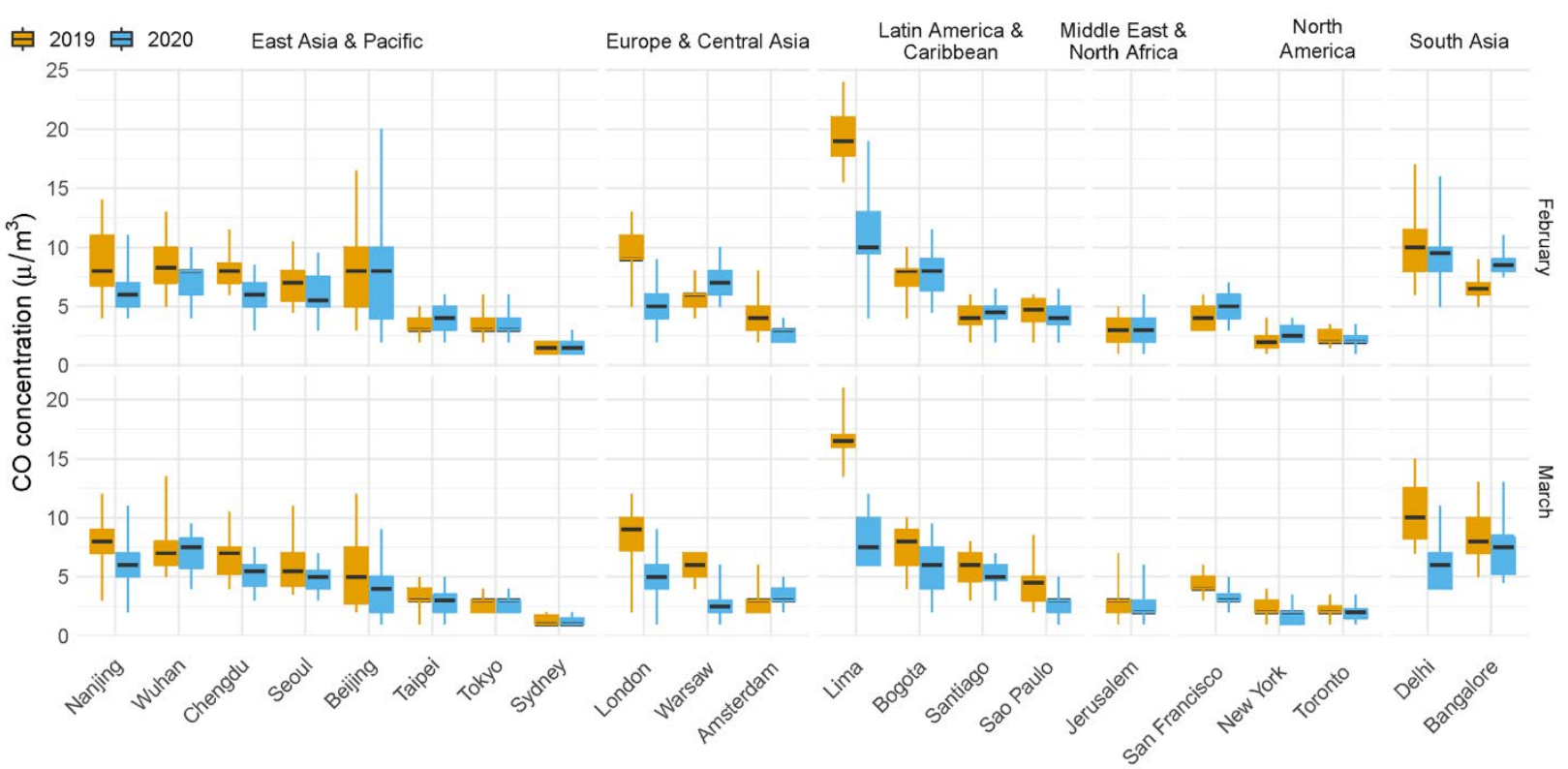

Figure 12. The box and whisker plots of daily average CO concentrations during FebruaryMarch 2020 and 2019. The top and bottom of each box represents $75^{\text {th }}$ percentile and $25^{\text {th }}$ percentile respectively and the upper and lower whisker represents $90^{\text {th }}$ percentile and $10^{\text {th }}$ percentile respectively. The horizontal bar in each box represents the median.

A number of previous studies have suggested that a swift and widespread implementation of science-based clean air solutions would result in multiple benefits such as improved public health, increased crop productivity, mitigating near-term climate change, and reduced socioeconomic costs due to improved air quality (e.g., UNEP, 2019). However, a simultaneous global scale, even a regional or a national scale, implementation of such air pollution control measures is almost next to impossible due to widely varying policy priorities of the countries around the world. Lockdowns introduced to contain the COVID-19 have led to a near-simultaneous shutdown of many sources of air pollutants at a global scale and has set a natural condition to examine the planetary scale reduction in air pollution albeit temporarily, and with massive suffering and socio-economic costs. 
This study provides the first insight on global scale pollution reduction caused by COVID-

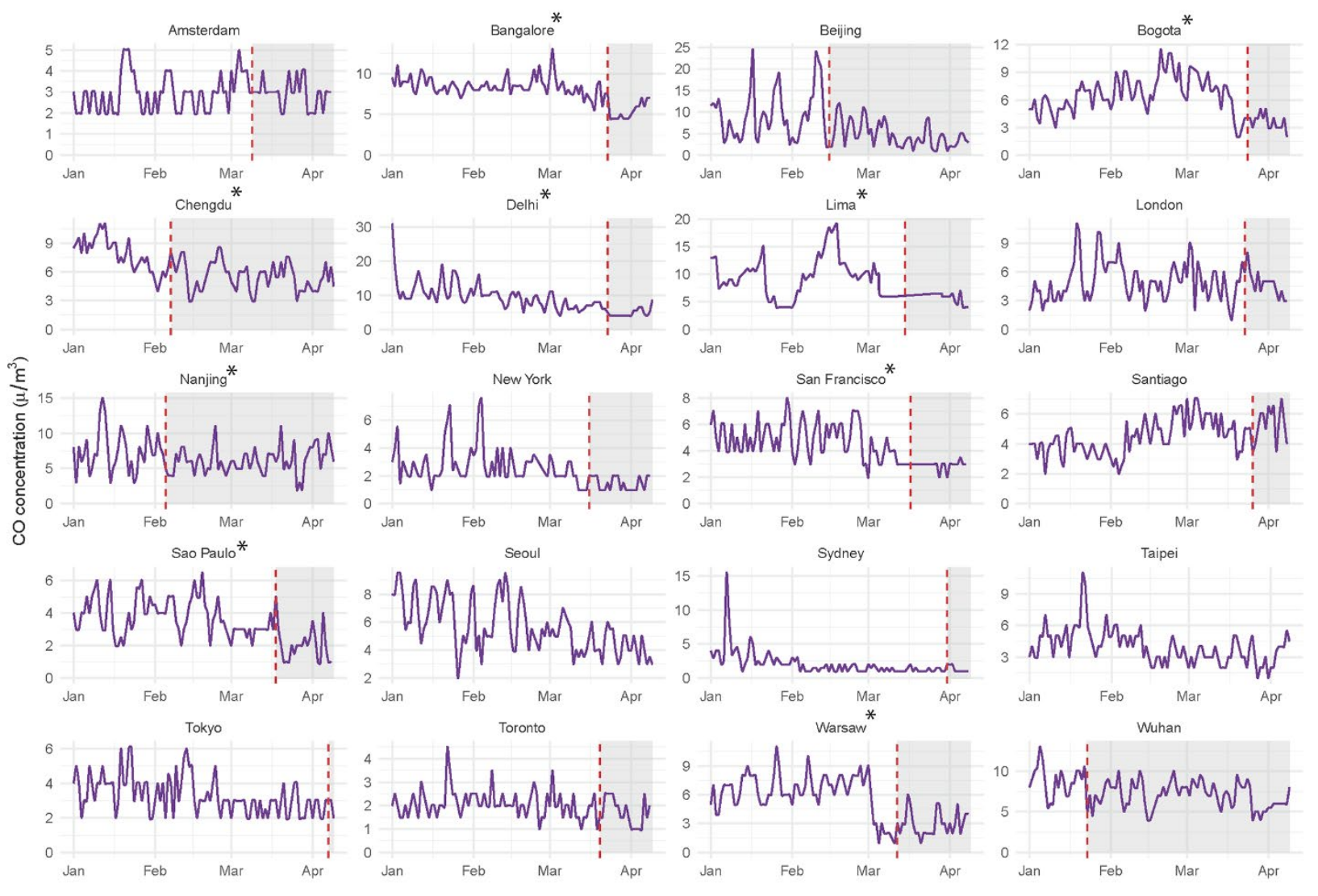

Figure 13. Time series of daily CO concentrations from January 1 to April 9, 2020 in 20 cities across the globe. Vertical red dashed line shows the lockdown date and $*$ denotes significant linear trends.

lockdown using comprehensive air pollution data collected from 301 stations located in 40 cities in 6 continents. Though the reduction is expected to be short-lived, it provides us encouraging evidence that a swift and widespread implementation of air pollution measures, as proposed by several scientific studies, can result in immediate air quality benefits. Yet, there is nothing to celebrate as the COVID-19 pandemic has taken an enormous toll on humanity and nobody wanted air pollution reduction this way. However, it is worth to note that the similar enormous damage has been caused by air pollution globally especially in the developing countries for at least last two decades which demands actions to reduce air pollution. 
The majority of the pre-existing health conditions such as respiratory and cardiovascular diseases that increase the risk of death for COVID-19 are the same diseases that are affected by long-term exposure to air pollution. In fact, air pollution aggravates the COVID-19 death rate (Wu et al. 2020). There are clear health benefits of air pollution reduction, including saving lives even during pandemic like COVID-19. The importance of continuing to enforce existing air pollution control regulations to protect human health both during and after the COVID-19 crisis cannot be and should not be ignored. While the enormous outpouring of support and global solidarity was seen that spurs numerous actions to mitigate, control, and eradicate COVID-19 pandemic, it is equally essential to show a similar level of urgency, solidarity and actions to address the great chronic environmental disasters of air pollution, a silent killer of approximately seven million people worldwide every year.

\section{References}

1. Achakulwisut, P., Brauer, M., Hystad, P., \& Anenberg, S. C. (2019). Global, national, and urban burdens of paediatric asthma incidence attributable to ambient $\mathrm{NO} 2$ pollution: estimates from global datasets. The Lancet Planetary Health, 3(4), e166-e178. https://doi.org/10.1016/S2542-5196(19)30046-4

2. ADB (2020). Developing Asia Growth to Fall in 2020 on COVID-19 Impact, News Release, Asian Development Bank (ADB), https://www.adb.org/news/developing-asiagrowth-fall-2020-covid-19-impact (Date accessed: April 6, 2020)

3. Brown, J. S. (2009). Acute effects of exposure to ozone in humans: how low can levels be and still produce effects?. American journal of respiratory and critical care medicine, 180(3), 200-201. https://doi.org/10.1164/rccm.200906-0834ED

4. Cadotte, M. (2020, March 30). Early evidence that COVID-19 government policies reduce urban air pollution. https://doi.org/10.31223/osf.io/nhgj3

5. Chandrashekhar, V. (2020) 1.3 billion people. A 21-day lockdown. Can India curb the coronavirus? Science doi:10.1126/science.abc0030

6. Chen, T. M., Kuschner, W. G., Gokhale, J., \& Shofer, S. (2007). Outdoor air pollution: nitrogen dioxide, sulfur dioxide, and carbon monoxide health effects. The American 
journal of the medical sciences, 333(4), 249-256. https://doi.org/10.1097/MAJ.0b013e31803b900f

7. Environmental Protection Agency (2014). Air Quality Index: A Guide to Air Quality and Your health. U.S. Environmental Protection Agency, Office of Air Quality Planning and Standards, https://www3.epa.gov/airnow/aqi brochure 02_14.pdf

8. GBD 2017 Risk Factor Collaborators. (2018). Global, regional, and national comparative risk assessment of 84 behavioural, environmental and occupational, and metabolic risks or clusters of risks for 195 countries and territories, 1990-2017: a systematic analysis for the Global Burden of Disease Study 2017. Lancet (London, England), 392(10159), 1923. https://doi.org/10.1016/S0140-6736(18)32225-6

9. He, G., Pan, Y., \& Tanaka, T. (2020). COVID-19, City Lockdown, and Air Pollution: Evidence from China. medRxiv. https://doi.org/10.1101/2020.03.29.20046649

10. Haines, A., Amann, M., Borgford-Parnell, N., Leonard, S., Kuylenstierna, J., \& Shindell, D. (2017). Short-lived climate pollutant mitigation and the Sustainable Development Goals. Nature Climate Change, 7(12), 863-869.

11. ILO (2020). ILO Monitor 2nd edition: COVID-19 and the world of work, Updated estimates and analysis https://www.ilo.org/wcmsp5/groups/public/@dgreports/@dcomm/documents/briefingnot e/wcms 740877.pdf (Date accessed: April 9, 2020)

12. Jing, G.(2020). Diary of a life in locked-down Wuhan https://www.bbc.com/news/worldasia-china-51276656 (Date accessed: April 1, 2020)

13. Kuo L. (2020) Liberation' as Wuhan's coronavirus lockdown ends after 76 days https://www.theguardian.com/world/2020/apr/07/liberation-as-wuhans-coronaviruslockdown-ends-after-76-days (Date accessed: April 9, 2020)

14. Sandford, A. (2020). Coronavirus: Half of humanity now on lockdown as 90 countries call for confinement https://www.euronews.com/2020/04/02/coronavirus-in-europespain-s-death-toll-hits-10-000-after-record-950-new-deaths-in-24-hou (Date accessed: April 9, 2020)

15. Singh, R. K. \& Chakraborty, D. (2020). Singh World's Dirtiest Air Gets Cleaner After India's Lockdown https://www.bloomberg.com/news/articles/2020-04-07/world-sdirtiest-air-gets-cleaner-after-india-s-lockdown (Date accessed: April 9, 2020) 
16. UNEP (2019). Air pollution in Asia and the Pacific: Science-based solutions, 1-250, UNEP, Nairobi, Kenya.

17. WHO (2020) Air Pollution http://www9.who.int/airpollution/en/ (Date accessed: April 8, 2020)

18. Wu, X., Nethery, R. C., Sabath, B. M., Braun, D., \& Dominici, F. (2020). Exposure to air pollution and COVID-19 mortality in the United States. medRxiv. https://doi.org/10.1101/2020.04.05.20054502 


\begin{tabular}{|c|c|c|c|c|c|c|c|}
\hline City & Country & Region* & Income group* & $\begin{array}{l}\text { Number } \\
\text { of } \\
\text { stations }\end{array}$ & $\begin{array}{l}\text { Lockdown } \\
\text { Start }\end{array}$ & $\begin{array}{l}\text { Lockdown } \\
\text { End }\end{array}$ & News Source \\
\hline Abu Dhabi & $\begin{array}{l}\text { United Arab } \\
\text { Emirates }\end{array}$ & $\begin{array}{l}\text { Middle East \& } \\
\text { North Africa }\end{array}$ & High income & 1 & $5 / 04 / 2020$ & On going & $\begin{array}{l}\text { https://www.outlookindia.com/outlooktraveller/t } \\
\text { ravelnews/story/70181/uae-begins-24-hour- } \\
\text { lockdown-for-two-weeks-from-april-5-to-contain- } \\
\text { the-covid-19 }\end{array}$ \\
\hline $\begin{array}{l}\text { Addis } \\
\text { Ababa }\end{array}$ & Ethiopia & $\begin{array}{l}\text { Sub-Saharan } \\
\text { Africa }\end{array}$ & Low income & 1 & $1 / 04 / 2020$ & On going & $\begin{array}{l}\text { https://www.aljazeera.com/news/2020/04/ethio } \\
\text { pia-declares-state-emergency-fight-covid-19- } \\
\text { 200408142519485.html }\end{array}$ \\
\hline Amsterdam & Netherlands & $\begin{array}{l}\text { Europe \& } \\
\text { Central Asia }\end{array}$ & High income & 5 & $9 / 03 / 2020$ & On going & $\begin{array}{l}\text { https://metro.co.uk/2020/03/19/trip- } \\
\text { amsterdam-showed-government-not-enough- } \\
\text { protect-us-coronavirus-12419537/ }\end{array}$ \\
\hline Bangalore & India & South Asia & $\begin{array}{l}\text { Lower middle } \\
\text { income }\end{array}$ & 5 & $\begin{array}{c}23 / 03 / 202 \\
0\end{array}$ & On going & $\begin{array}{l}\text { https://en.wikipedia.org/wiki/2020_coronavirus_ } \\
\text { pandemic_in_India }\end{array}$ \\
\hline Bangkok & Thailand & $\begin{array}{l}\text { East Asia \& } \\
\text { Pacific }\end{array}$ & $\begin{array}{l}\text { Upper middle } \\
\text { income }\end{array}$ & 4 & $\begin{array}{c}23 / 03 / 202 \\
0\end{array}$ & On going & $\begin{array}{l}\text { https://www.ctvnews.ca/health/coronavirus/thail } \\
\text { and-imposes-state-of-emergency-to-control- } \\
\text { coronavirus-1.4865483 }\end{array}$ \\
\hline Beijing & China & $\begin{array}{l}\text { East Asia \& } \\
\text { Pacific }\end{array}$ & $\begin{array}{l}\text { Upper middle } \\
\text { income }\end{array}$ & 26 & $\begin{array}{c}15 / 02 / 202 \\
0\end{array}$ & $\begin{array}{l}24 / 03 / 202 \\
0\end{array}$ & $\begin{array}{l}\text { https://www.forbes.com/sites/siminamistreanu/2 } \\
\text { 020/03/27/beijing-has-defeated-coronavirus- } \\
\text { what-it-was-like-living-in-the-locked-down-city- } \\
\text { for-two-months/\# }\end{array}$ \\
\hline Bern & Switzerland & $\begin{array}{l}\text { Europe \& } \\
\text { Central Asia }\end{array}$ & High income & 1 & $\begin{array}{c}19 / 03 / 202 \\
0\end{array}$ & On going & $\begin{array}{l}\text { https://www.swissinfo.ch/eng/covid-19_bern-in- } \\
\text { the-time-of-coronavirus/45625916 }\end{array}$ \\
\hline Bogota & Colombia & $\begin{array}{l}\text { Latin } \\
\text { America \& } \\
\text { Caribbean }\end{array}$ & $\begin{array}{l}\text { Upper middle } \\
\text { income }\end{array}$ & 14 & $\begin{array}{c}24 / 03 / 202 \\
0\end{array}$ & On going & $\begin{array}{l}\text { https://www.aa.com.tr/en/americas/national- } \\
\text { lockdown-starts-in-colombia-amid- } \\
\text { protests/1779226 }\end{array}$ \\
\hline $\begin{array}{l}\text { Buenos } \\
\text { Aires }\end{array}$ & Argentina & $\begin{array}{l}\text { Latin } \\
\text { America \& } \\
\text { Caribbean }\end{array}$ & $\begin{array}{l}\text { Upper middle } \\
\text { income }\end{array}$ & 1 & $\begin{array}{c}20 / 03 / 202 \\
0\end{array}$ & On going & $\begin{array}{l}\text { https://www.latinfinance.com/daily- } \\
\text { briefs/2020/3/31/argentina-braces-for-gradual- } \\
\text { economic-recovery-after-lockdown }\end{array}$ \\
\hline
\end{tabular}




\begin{tabular}{|c|c|c|c|c|c|c|c|}
\hline Chengdu & China & $\begin{array}{l}\text { East Asia \& } \\
\text { Pacific }\end{array}$ & $\begin{array}{l}\text { Upper middle } \\
\text { income }\end{array}$ & 10 & $2 / 07 / 2020$ & On going & $\begin{array}{l}\text { http://society.people.com.cn/n1/2020/0207/c100 } \\
\text { 8-31576755.html }\end{array}$ \\
\hline Delhi & India & South Asia & $\begin{array}{l}\text { Lower middle } \\
\text { income }\end{array}$ & 14 & $\begin{array}{c}23 / 03 / 202 \\
0\end{array}$ & On going & $\begin{array}{l}\text { https://en.wikipedia.org/wiki/2020_coronavirus_ } \\
\text { pandemic_in_India }\end{array}$ \\
\hline Dhaka & Bangladesh & South Asia & $\begin{array}{l}\text { Lower middle } \\
\text { income }\end{array}$ & 1 & $\begin{array}{c}26 / 03 / 202 \\
0\end{array}$ & On going & $\begin{array}{l}\text { https://www.aa.com.tr/en/asia-pacific/covid-19- } \\
\text { bangladesh-extends-shutdown-until-april- } \\
11 / 1786610\end{array}$ \\
\hline Dublin & Ireland & $\begin{array}{l}\text { Europe \& } \\
\text { Central Asia }\end{array}$ & High income & 2 & $\begin{array}{c}24 / 03 / 202 \\
0\end{array}$ & On going & $\begin{array}{l}\text { https://en.wikipedia.org/wiki/2020_coronavirus_ } \\
\text { pandemic_in_the_Republic_of_Ireland\#COVID- } \\
\text { related_offences }\end{array}$ \\
\hline $\begin{array}{l}\text { Ho Chi Minh } \\
\text { City }\end{array}$ & Vietnam & $\begin{array}{l}\text { East Asia \& } \\
\text { Pacific }\end{array}$ & $\begin{array}{l}\text { Lower middle } \\
\text { income }\end{array}$ & 1 & $\begin{array}{c}31 / 03 / 202 \\
0\end{array}$ & On going & $\begin{array}{l}\text { https://www.voanews.com/science- } \\
\text { health/coronavirus-outbreak/vietnam-latest-lock- } \\
\text { down-while-us-braces-huge-death-toll }\end{array}$ \\
\hline Istanbul & Turkey & $\begin{array}{l}\text { Europe \& } \\
\text { Central Asia }\end{array}$ & $\begin{array}{l}\text { Upper middle } \\
\text { income }\end{array}$ & 4 & $2 / 04 / 2020$ & On going & $\begin{array}{l}\text { https://en.qantara.de/content/turkey-mayor- } \\
\text { urges-lockdown-for-istanbul }\end{array}$ \\
\hline Jakarta & Indonesia & $\begin{array}{l}\text { East Asia \& } \\
\text { Pacific }\end{array}$ & $\begin{array}{l}\text { Lower middle } \\
\text { income }\end{array}$ & 3 & $\begin{array}{c}10 / 04 / 202 \\
0\end{array}$ & On going & $\begin{array}{l}\text { https://www.thestar.com.my/news/regional/202 } \\
0 / 04 / 08 / \text { jakarta-to-impose-partial-lockdown-on- } \\
\text { april-10 }\end{array}$ \\
\hline Jerusalem & Israel & $\begin{array}{l}\text { Middle East \& } \\
\text { North Africa }\end{array}$ & High income & 3 & $7 / 04 / 2020$ & On going & $\begin{array}{l}\text { https://www.i24news.tv/en/news/israel/158619 } \\
\text { 2909-israel-s-netanyahu-announces-new-anti- } \\
\text { coronavirus-restrictions }\end{array}$ \\
\hline Kampala & Uganda & $\begin{array}{l}\text { Sub-Saharan } \\
\text { Africa }\end{array}$ & Low income & 1 & $\begin{array}{c}30 / 03 / 202 \\
0\end{array}$ & On going & $\begin{array}{l}\text { https://www.kfm.co.ug/entertainment/photos- } \\
\text { empty-streets-of-kampala-after-lockdown.html }\end{array}$ \\
\hline Kathmandu & Nepal & South Asia & Low income & 4 & $\begin{array}{c}24 / 03 / 202 \\
0\end{array}$ & On going & $\begin{array}{l}\text { https://nep123.com/covid-19-kathmandu-valley- } \\
\text { wears-a-disserted-look-with-lockdown- } \\
\text { enforcement/ }\end{array}$ \\
\hline Lima & Peru & $\begin{array}{l}\text { Latin } \\
\text { America \& } \\
\text { Caribbean }\end{array}$ & $\begin{array}{l}\text { Upper middle } \\
\text { income }\end{array}$ & 11 & $\begin{array}{c}15 / 03 / 202 \\
0\end{array}$ & On going & $\begin{array}{l}\text { https://www.miningmagazine.com/covid- } \\
\text { 19/news/1383191/covid-19-lock-down-affects- } \\
\text { miners-in-peru }\end{array}$ \\
\hline London & $\begin{array}{l}\text { United } \\
\text { Kingdom }\end{array}$ & $\begin{array}{l}\text { Europe \& } \\
\text { Central Asia }\end{array}$ & High income & 20 & $\begin{array}{c}23 / 03 / 202 \\
0\end{array}$ & On going & $\begin{array}{l}\text { https://www.nytimes.com/2020/03/24/world/eu } \\
\text { rope/britain-coronavirus-lockdown.html }\end{array}$ \\
\hline Madrid & Spain & $\begin{array}{l}\text { Europe \& } \\
\text { Central Asia }\end{array}$ & High income & 4 & $\begin{array}{c}14 / 03 / 202 \\
0\end{array}$ & On going & $\begin{array}{l}\text { https://en.as.com/en/2020/03/26/other_sports/ } \\
\text { 1585233133_070352.html }\end{array}$ \\
\hline
\end{tabular}




\begin{tabular}{|c|c|c|c|c|c|c|c|}
\hline Nanjing & China & $\begin{array}{l}\text { East Asia \& } \\
\text { Pacific }\end{array}$ & $\begin{array}{l}\text { Upper middle } \\
\text { income }\end{array}$ & 3 & $5 / 02 / 2020$ & On going & $\begin{array}{l}\text { https://en.wikipedia.org/wiki/2020_Hubei_lockdo } \\
\text { wns }\end{array}$ \\
\hline New York & $\begin{array}{l}\text { United } \\
\text { States }\end{array}$ & $\begin{array}{l}\text { North } \\
\text { America }\end{array}$ & High income & 12 & $\begin{array}{c}16 / 03 / 202 \\
0\end{array}$ & On going & $\begin{array}{l}\text { https://news.sky.com/story/coronavirus-new- } \\
\text { york-and-la-on-lockdown-as-world-reacts-to- } \\
\text { spread-of-covid-19-11958145 }\end{array}$ \\
\hline Oslo & Norway & $\begin{array}{l}\text { Europe \& } \\
\text { Central Asia }\end{array}$ & High income & 3 & $\begin{array}{c}12 / 03 / 202 \\
0\end{array}$ & On going & $\begin{array}{l}\text { https://en.wikipedia.org/wiki/2020_coronavirus_ } \\
\text { pandemic_in_Norway }\end{array}$ \\
\hline Paris & France & $\begin{array}{l}\text { Europe \& } \\
\text { Central Asia }\end{array}$ & High income & 11 & $\begin{array}{c}17 / 03 / 202 \\
0\end{array}$ & On going & $\begin{array}{l}\text { https://www.aa.com.tr/en/europe/parisians- } \\
\text { vacate-city-ahead-of-covid-19-lockdown/1769664 }\end{array}$ \\
\hline Rome & Italy & $\begin{array}{l}\text { Europe \& } \\
\text { Central Asia }\end{array}$ & High income & 10 & $\begin{array}{c}11 / 03 / 202 \\
0\end{array}$ & On going & $\begin{array}{l}\text { https://www.repubblica.it/politica/2020/03/11/ } \\
\text { news/coronavirus_conte_italia_governo_misure- } \\
\text { 250988471/?ref=RHPPTP-BL-I250988111-C12- } \\
\text { P1-S1.12-T1 }\end{array}$ \\
\hline $\begin{array}{l}\text { San } \\
\text { Francisco }\end{array}$ & $\begin{array}{l}\text { United } \\
\text { States }\end{array}$ & $\begin{array}{l}\text { North } \\
\text { America }\end{array}$ & High income & 7 & $\begin{array}{c}17 / 03 / 202 \\
0\end{array}$ & On going & $\begin{array}{l}\text { https://www.aa.com.tr/en/americas/us-san- } \\
\text { francisco-under-3-week-coronavirus-lock- } \\
\text { down/1768830 }\end{array}$ \\
\hline Santiago & Chile & $\begin{array}{l}\text { Latin } \\
\text { America \& } \\
\text { Caribbean }\end{array}$ & High income & 6 & $\begin{array}{c}26 / 03 / 202 \\
0\end{array}$ & On going & $\begin{array}{l}\text { https://en.wikipedia.org/wiki/2020_coronavirus_ } \\
\text { pandemic_in_Chile\#Government_response }\end{array}$ \\
\hline Sao Paulo & Brazil & $\begin{array}{l}\text { Latin } \\
\text { America \& } \\
\text { Caribbean }\end{array}$ & $\begin{array}{l}\text { Upper middle } \\
\text { income }\end{array}$ & 14 & $\begin{array}{c}18 / 03 / 202 \\
0\end{array}$ & On going & $\begin{array}{l}\text { https://www.aa.com.tr/en/americas/death-toll-in- } \\
\text { brazil-from-covid-19-rises-to-159/1785792 }\end{array}$ \\
\hline Seoul & South Korea & $\begin{array}{l}\text { East Asia \& } \\
\text { Pacific }\end{array}$ & High income & 6 & $\begin{array}{c}\text { No } \\
\text { lockdown }\end{array}$ & On going & \\
\hline Sydney & Australia & $\begin{array}{l}\text { East Asia \& } \\
\text { Pacific }\end{array}$ & High income & 17 & $\begin{array}{c}31 / 03 / 202 \\
0\end{array}$ & On going & $\begin{array}{l}\text { https://www.theguardian.com/australia- } \\
\text { news/2020/apr/01/social-distancing-rules- } \\
\text { australia-lockdown-coronavirus-strict-new-laws- } \\
\text { legal-illegal-state-physical-restrictions-guidelines- } \\
\text { explained-nsw-victoria-qld-queensland-act-sa-wa- } \\
\text { two-person }\end{array}$ \\
\hline Taipei & Taiwan & $\begin{array}{l}\text { East Asia \& } \\
\text { Pacific }\end{array}$ & High income & 1 & $\begin{array}{l}\text { No } \\
\text { lockdown }\end{array}$ & On going & \\
\hline Tashkent & Uzbekistan & $\begin{array}{l}\text { Europe \& } \\
\text { Central Asia }\end{array}$ & $\begin{array}{l}\text { Lower middle } \\
\text { income }\end{array}$ & 1 & $\begin{array}{c}24 / 03 / 202 \\
0\end{array}$ & On going & $\begin{array}{l}\text { http://www.china.org.cn/world/Off_the_Wire/202 } \\
\text { 0-03/23/content_75850320.htm }\end{array}$ \\
\hline
\end{tabular}




\begin{tabular}{|c|c|c|c|c|c|c|c|}
\hline Tokyo & Japan & $\begin{array}{l}\text { East Asia \& } \\
\text { Pacific }\end{array}$ & High income & 20 & $7 / 04 / 2020$ & On going & $\begin{array}{l}\text { https://edition.cnn.com/2020/04/07/asia/japan- } \\
\text { coronavirus-state-of-emergency-intl- } \\
\text { hnk/index.html }\end{array}$ \\
\hline Toronto & Canada & $\begin{array}{l}\text { North } \\
\text { America }\end{array}$ & High income & 12 & $\begin{array}{l}20 / 03 / 202 \\
0\end{array}$ & On going & $\begin{array}{l}\text { https://www.cbc.ca/news/canada/toronto/coron } \\
\text { avirus-covid-19-ontario-friday-online-learning- } \\
1.5504109\end{array}$ \\
\hline Ulaanbaatar & Mongolia & $\begin{array}{l}\text { East Asia \& } \\
\text { Pacific }\end{array}$ & $\begin{array}{l}\text { Lower middle } \\
\text { income }\end{array}$ & 6 & $\begin{array}{c}10 / 03 / 202 \\
0\end{array}$ & On going & $\begin{array}{l}\text { https://www.garda.com/crisis24/news- } \\
\text { alerts/321181/mongolia-government-places- } \\
\text { ulaanbaatar-and-other-cities-on-lockdown-due-to- } \\
\text { covid-19-march-10-update-7 }\end{array}$ \\
\hline Vienna & Austria & $\begin{array}{l}\text { Europe \& } \\
\text { Central Asia }\end{array}$ & High income & 12 & $\begin{array}{l}18 / 03 / 202 \\
0\end{array}$ & On going & https://metropole.at/coronavirus-in-austria/ \\
\hline Warsaw & Poland & $\begin{array}{l}\text { Europe \& } \\
\text { Central Asia }\end{array}$ & High income & 3 & $\begin{array}{l}12 / 03 / 202 \\
0\end{array}$ & On going & $\begin{array}{l}\text { https://en.wikipedia.org/wiki/2020_coronavirus_ } \\
\text { pandemic_in_Poland }\end{array}$ \\
\hline Wuhan & China & $\begin{array}{l}\text { East Asia \& } \\
\text { Pacific }\end{array}$ & $\begin{array}{l}\text { Upper middle } \\
\text { income }\end{array}$ & 21 & $\begin{array}{l}23 / 01 / 202 \\
0\end{array}$ & $\begin{array}{c}24 / 03 / 202 \\
0\end{array}$ & $\begin{array}{l}\text { https://news.cgtn.com/news/2020-04-01/Study- } \\
\text { China-lockdown-may-have-blocked-700-000- } \\
\text { COVID-19-cases-PkzcYgVj32/index.html }\end{array}$ \\
\hline
\end{tabular}

Country specific classification of income group and region were adopted from the World Bank (https://blogs.worldbank.org/opendata/new-countryclassifications-income-level-2019-2020, accessed April 7, 2020). 
